Utah State University

DigitalCommons@USU

All U.S. Government Documents (Utah Regional U.S. Government Documents (Utah Regional Depository)

Depository)

1990

\title{
Mineral Resources of the Marble Canyon Wilderness Study Area, White Pine County, Nevada, and Millard County, Utah
}

\author{
Michael F. Diggles \\ Gary A. Nowlan \\ H. Richard Blank, Jr. \\ Susan M. Marcus \\ Richard F. Kness \\ U.S. Geological Survey
}

See next page for additional authors

Follow this and additional works at: https://digitalcommons.usu.edu/govdocs

Part of the Natural Resources and Conservation Commons

\section{Recommended Citation}

Diggles, Michael F.; Nowlan, Gary A.; Blank, Jr., H. Richard; Marcus, Susan M.; Kness, Richard F.; U.S. Geological Survey; and U.S. Bureau of Mines, "Mineral Resources of the Marble Canyon Wilderness Study Area, White Pine County, Nevada, and Millard County, Utah" (1990). All U.S. Government Documents (Utah Regional Depository). Paper 558.

https://digitalcommons.usu.edu/govdocs/558

This Report is brought to you for free and open access by the U.S. Government Documents (Utah Regional Depository) at DigitalCommons@USU. It has been accepted for inclusion in All U.S. Government Documents (Utah Regional Depository) by an authorized administrator of DigitalCommons@USU. For more information, please contact digitalcommons@usu.edu.

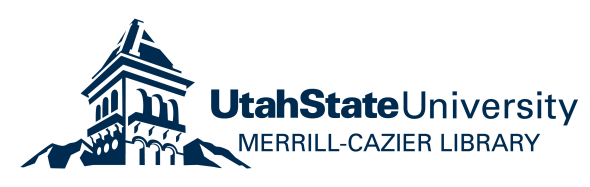


Authors

Michael F. Diggles; Gary A. Nowlan; H. Richard Blank, Jr.; Susan M. Marcus; Richard F. Kness; U.S. Geological Survey; and U.S. Bureau of Mines 
U.S. DEPARTMENT OF THE INTERIOR UNITED STATES GEOLOGICAL SURVEY

MINERAL RESOURCES OF THE MARBLE CANYON WILDERNESS STUDY AREA, WHITE PINE COUNTY,

NEVADA, AND MILLARD COUNTY, UTAH

By

Michael F. Diggles ${ }^{1}$, Gary A. Nowlan ${ }^{2}$, H. Richard Blank, Jr. ${ }^{2}$, and Susan M. Marcus ${ }^{3}$ U.S. Geclogical Survey

and

Richard F. Kness ${ }^{2}$

U.S. Bureau of Mines

\section{STUDIES RELATED TO WILDERNESS}

Bureau of Land Management Wilderness Study Area

The Fec'ral Land Policy and Management Act (Public Law 94-579, October 21, 1976) requires the U.S. Geological Survey and U.S. Bureau of Mines to conduct mineral surveys on certain areas to determine the mineral values, if any, that may be present. Results must be made available to the public and be submitted to the President and the Congress. This report presents the results of a mineral survey of part of the Marble Canyon (NV-040-086) Wilderness Study Area, White Pine County, Nevada, and Millard County, Utah.

U.S. Geological Survey Open-File Report 90-0522

Prepared by the U.S. Geological Survey and the U.S. Bureau of Mines

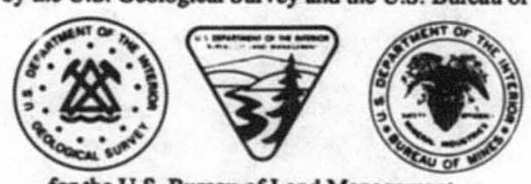

for the U.S. Bureau of Land Management

This report is preliminary and has not been reviewed for conformity with U.S. Geological Survey oditorial standards or with the North American stratignaphic code. Any use of trade, product, or firm names is for descriptive purposes only and does not imply 
FIGURES

1. Index map showing location of the Marble Canyon Wilderness Study Area, White Pine

2. Mineral resource potential and generalized geology of the Marble Canyon Wilderness

3. Geochemical anomaly map of the Marble Canyon Wildemess Study Area, Nevada and

3. Utah. 16

4. Aeromagnetic map of the Marble Canyon Wilderness Study Area, Nevada and Utah. 20 Bouguer gravity anomaly map of the Marble Canyon Wilderness Study Area, Nevada

TABLE

1. Statistics for selected elements in drainage sampler collected in and near the Marble Canyon Wilderness Study Area, Nevada and Mil ud County, Utah. 18
Abstract

The 19,150-acre Marble Canyon Wilderness Study Area (NV-040-086) was evaluated for mineral resources (known) and mineral resource potential (undiscovered), and field work was conducted in 1987. The acreage includes 6,435 acres that is now designated as part of the Mount Moriah Wilderness under the Nevada Wildertiess Protection Act of 1989 (S. 974), most but not all of which is included in 8,300 acres for which the U.S. Bureau of Land Management requested a mineral survey. In this repor, the "wilderness study area," or simply the study area" relers to the entire 19,150-acre

The area is underlain by queitzite shale and carbonate rocks. The northern Snake Range décollement is a detachment surface within the study area that separates rocks of similar age but different metamorphic grade. Large inferred subeconomic limestone and marble resources in the study area have no special or unique properties. The mineral resource potential for limestone and marble is high in two canyons and is moderate in the rest of the wilderness study area. Parts of the study area above and along the northern Snake Range décollement have low potential for undisc vered deposits of gold, silver, copper, lead, zinc, tungsten, molybdenum, beryllium, and bound $y$ of the sudy area has moderte pontial for barite and the surround has low potential for zinc, and tungsten. The entire study area has moderate potential for oil and gas and low potential for geothermal energy resources.

\section{Character and Setting}

The Marble Canyon Wilderness Study Area covers approximately 19,150 acres and is 10 mi west of Gandy, Utah (fig. 1). The terrain is rugged, and the elevation ranges from about 9,33 in ar The Canyon, and Smith Creek.

The study area is underlain by shales, quartzites, and carbonate rocks of early Paleozoic

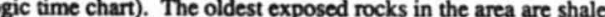
quartzite, and marble of Early and Middle Cambrian age. Shale of Late Cambrian age has been lauited over the older metamorphosed rocks. Dolomite, shale, and quartzite of Ordovician and Silurian age are also in fault contact with the Upper Cambrian rocks. The structural history of the study area includes the development of a detachment fault that juxtaposes metamorphosed nonmetamorphosed rocks. This detachment surface is part of the nct

\section{Identified Mineral Resources}

Limestone has been prospected and quarried in and near the study area. Large inferred subeconomic limestone and marble resources inside the study area are without special or unique properties. The carbonate rocks are suitable for use in aggregate, but there are no nearby markets and similar quality resources are present elsewhere. 


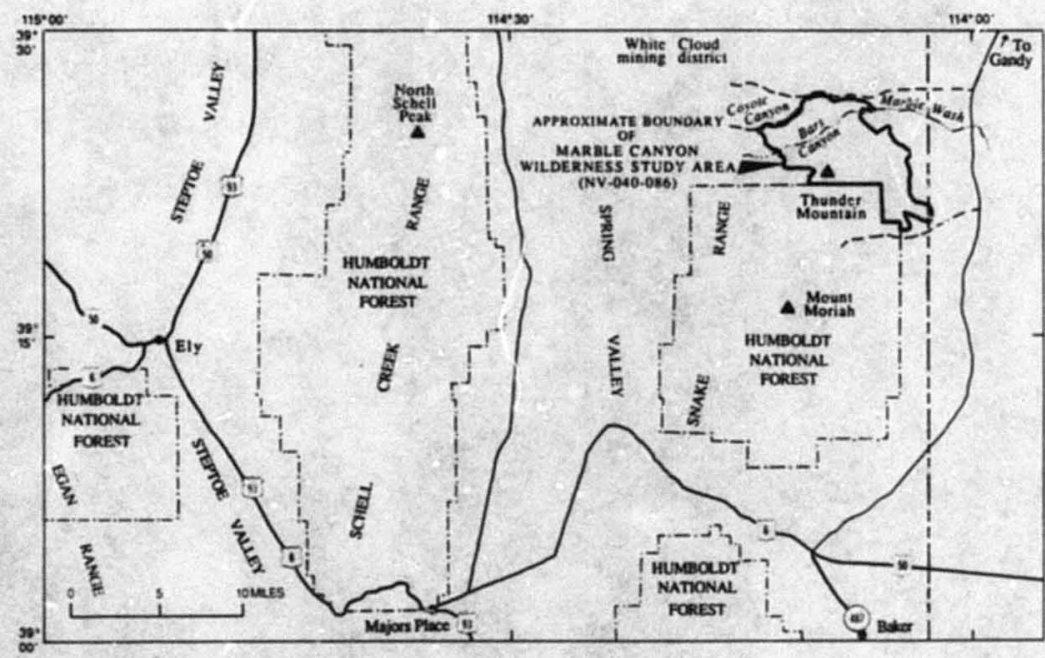

The exposed northerm Snake Range decollement within the study area is not mineralized, as indicated by a lack of surface expressions and by stream-sediment data. Samples taken from fault-breccia zones in nonmetamorphosed carbonate rocks above the northern Snake Range decollement contain some pathfinder
mineral oceurrences were observed.

Mineral Resource Potential

In the lower parts of Bars Canyon and Marble Wash the mineral resource potential for limestone and marble is high, and in the rest of the study area it is moderate.

Areas of the Marble Canyon Wilderness Study Area underlain by upper-plate rocks and the zone of the northern Snake Range decollement have low mineral resource potential for gold, silver, copper, lead, zinc, tungsten, mo.ybdenum, beryllium, and fluorite. The gold and silver are associated with low-angie faults within those areas. Geochemical evidence suggests the resource potential for copper, lead, zinc, tungsten, and molybdenum in those areas. The geophysical study suggests that ho plutons are buried beneath the study area, but anomaious concentrations .

Adits inside the southeast boundary of the study area reveal exposures of barite, and anomalous concentrations of barium were measured in geochemical samples from upper-plate
rocks there. A narrow zone around the adits has moderate mineral resource potential for barite, and the surrounding area has low mineral resource potential for barite. On the basis of geochemical data, the adits and a wider zone around them have low mineral resource potential for silver, copper, lead, zinc, and tungsten.

The metamorphosed lower plate rocks, the thin sequences of faulted upper plate rocks, and the extrusive volcanic rocks exposed in the study area are not conducive to the formation and accumulation of hydrocarbons. The resource potential for oil and gas in the entire study area is moderate, but this assessment may be too high due to the lack of likely source rocks. There are two thermal springs in Spring Valley to the west of the study area and other thermal springs just east of the study area. Range-front faults in the region may provide a conduit for the circulation of thermal water, and such a system could extend into the study area. Therefore, the entire Marble Canyon Wilderness Study Area has low potential for geothermal energy resources associated with low-temperature thermal springs.

INTRODUCTION

This mineral survey was requested by the U.S. Bureau of Land Management and is the result of a cooperative effort by the U.S. Geological Survey and the U.S. Bureau of Mines. An introduction to the wilderness review process, mineral survey methods, and agency

responsibilities was provided by Beikman and others (1983). The U.S. Bureau of Mines evaluates identified resources at individual mines and known mineralized areas by collecting data on current and past mining activities and through field examination of mines, prospects, claims, and mineralized areas. Identified resources are classified according to a system that is modification of that described by McKelvey (1972) and U.S. Bureau of Mines and U.S Geological Survey (1900). U.S. Ceologica Sarvey studies are desig bed to provide a scientific ermining geologic units and stuctures, possible environments of mineral deposition, presence of geochemical and geophyent the definition of levels of mineral resource potential and certainty of assessment and for the

Figure 1,-Index map showing location of Marble Canyon Wildemess Study Area, White Pine resource/reserve classification. 
Location and Physiography

The Marble Canyon Wilderness Study Area comprises approximately 19,150 acres in the Basin and Range physiographic province. It is situated in the northern Snake Range, principally mi southwest of Gandy, Utah. The north and west boundaries follow Marble Wash and Cout 10 Canyon, respectively. The south boundary follows a four-wheel-drive road from Coyote Canyon to the base of Thunder Mountain and the north boundary of the Mount Moriah Division of Humboldt National Forest. The east boundary follows a four-wheel-drive road along the alluvial apron near the 6,000-ft contour. Elevations in the study area range from about $9,331 \mathrm{ft}$ at

Wilderness Protection Act of 1989 designates 6,435 acres of the study area as part of the Moun Moriah Wilderness (fig. 1).

Climate in the study area is classified as arid; precipitation averages $10 \mathrm{in}$. per year and supports vegetation of the Sonoran and Transition Zones. The higher elevations are in the Transition Zone where vegetatiun includes piñon and bristlecone pine. Bristlecone pines grow primarily on limestone and are conspicuously absent from hillsides underlain by quartzite. The middle elevations are in the Upper Sonoran Zone and support white fir and incense cedar. On the dryer lower slopes, the vegetation is typically Lower Sonoran sagebrush and mountain mahogany.

Procedures and Sources of Data

The U.S. Geological Survey and the U.S. Bureau of Mines conducted detailed field investigations of the Marble Canyon Wilderness Study Area in the summer of 1987. This work included geologic mapping at a scale of 1:24,000, field checiks of existing geologic maps.
gecchemical sampling, and the examination of outcrops for evidence of mineralization.

A detailed literature search was made for geologic and mining information pertinent to the study area, and U.S. Bureau of Land Management records were examined for information on mining clains and oil and gas leases. Two U.S. Bureau of Mines geologists spent 6 days in the and they collected 21 rock and 19 stream-sediment saf prospects with and near the study are either by inductively coupled plasme-atomic emission specturoseopy samples were analyzed absorption methods by Chemex Labs Inc. Sparks, Ney. Sample data were discussed by $\mathrm{K}$. (1989) and are summarized in this report. Complete sample data are available for public Kness inspection at the U.S. Bureau of Mines, Intermountain Field Operations Center, Building 20 Denver Federal Center, Denver, CO.

General stratigraphic studies in the region include a correlation of stratigraphic units in the Great Basin (Langenheim and Larson, 1973), a description of the stratigraphic section near Eureka, Nev. (Nolan and others, 1956), and paleogeographic interpretations (Stewart and others Cambrian strata (rewaphic studies include descriptions of upper Precambrian and Lower Cambrian strata (Palmer, 1960). Whitebread and Lee (1961) and Whitebread (1960), and Upper the geology of the Wheeler Peak area in what is now Great Basin National Park, 15 mi south of the study area. Hose and Blake (1970. of White Pine County, and Hose (1981) presented the geology of the Mount Moriah Division of Humboldt National Forest (formerily the Mount Moriah Roadless Area and now included in the Mount Moriah Widermess). Christiansen and others (1987) did detailed mapping just south of the study area. The geology in the western part of figure 2 is generalized from detailed mapping

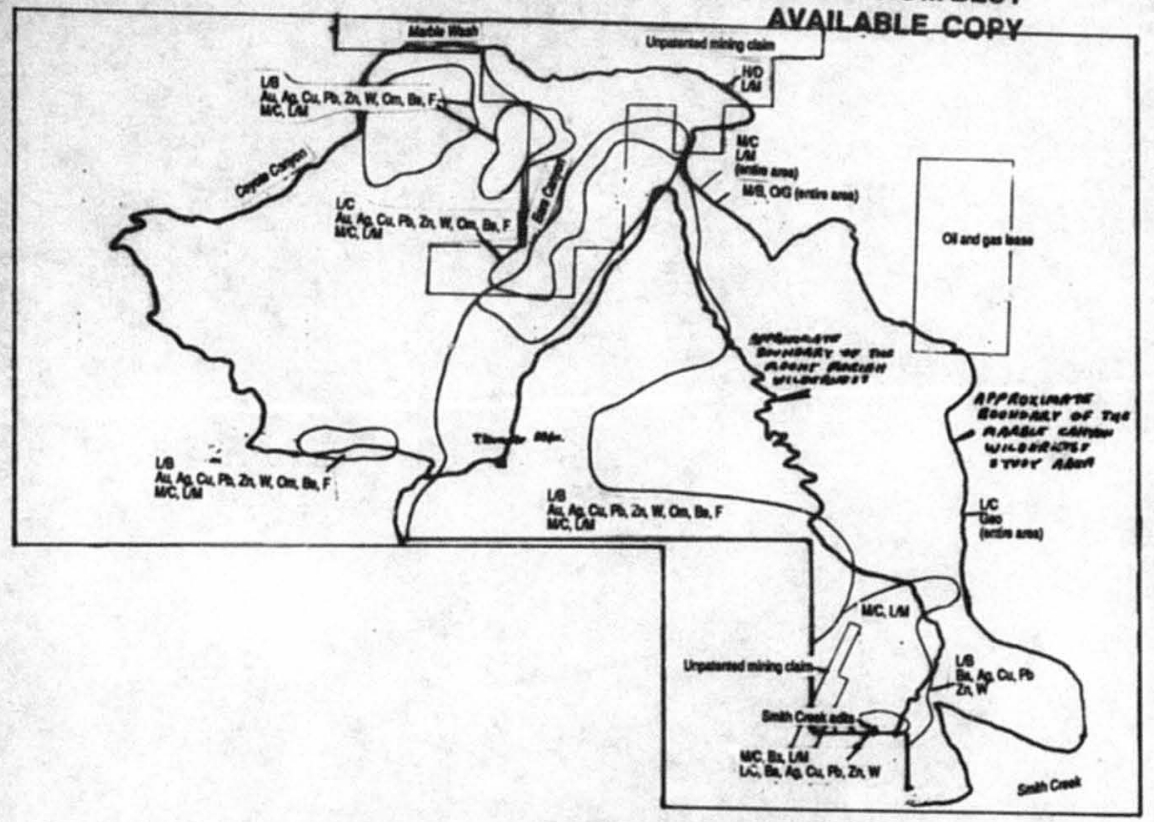

EXPLANATION

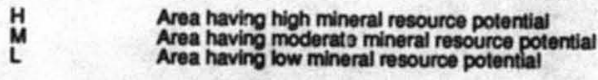

B
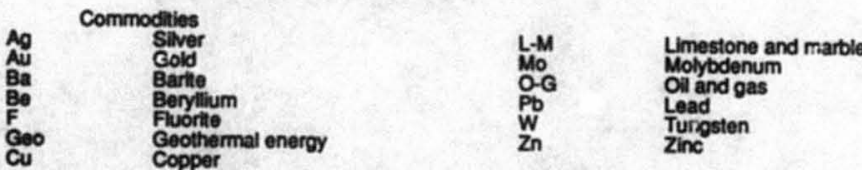

Figure 2.-Mineral resource pottutial and generalized geology of Marble Canyon Wildernes Study Area, White Pine County, Nevada, and Millard County, Utah. Geology generalized from Lee (1987) and unpublished mapping of Jeffrey Lee (written commun.
1989). 
General treatments of the structural geology of the region include studies of centralnortheastern Nev da (Misch, 1960; Misch and Hazzard, 1962) and descriptions of the structural evolution of the eastern Great Basin (Hose and Danes, 1968, 1973; Hose and Blake, 1969). Hazzard and others (1953) and Nelson (1966) described the structural development of the region, including the large-scale thrust faulting in the northern Snake Range, a theory that has been superseded by the interpretation of the northern Snake Range decollement (Wernicke, 198 Miller and others, 1983). Whitebread (1966), Coney (1974), Rowles (1982), and McGrew (1986) specifically addressed tie northem. Saake Range decollement. Gering (1987), Miller and

General treatments of mineral resources include a bibliography of Nevada resources (Weimer-McMillion and others, 1983), a map of resource areas in Nevada (Wong, 1983), and a description of computer-accessible Nevada mineral-resource data (Sherlock and Tingley, 1985). Cox and Singer (1986) presented mineral-deposit and grade-tonnage models. Lincoln (1923) provided an early treatment of mining districts in Nevada. Morton and others (1977) provided age data on ore deposits in Nevada. Darton (1908) reported on marble in White Pine County. Smith (1976) reported on the mineral resources of White Pine County, and Carlson and others 1984) presented the mineral resource potential of the Mount Moriah Division of Humboldt (Geat Basin GEM Maint Vement 1983). Bullock and others (1989) presented the data from the U.S. Geological Survey streamsediment sampling progran for this wilderness study area. Kness (1989) presented the results of the U.S. Bureau of Mines mineral resource appraisal for this wilderness study area.

Acknowledgments

The authors greatly appreciate the cooperation of Shaaron Netherton, William D. Robison, and Brian Amme of the U.S. Bureau of Land Management in Ely. Nev. Carl and Jeffrey Lee shared unpublished mapping that is par of his $\mathrm{Ph}$ D dissertation at Stanford University. Elizabeth Miller and her students from Stanford University shared detailed geologic mapping information on the northern Snake Range. R.A. Schreiner assis ' the U.S. Bureau of Mines author with his field studies.

\section{APPRAISAL OF IDENTIFIED RESOURCES}

By Richard F. Kness

U.S. Bureau of Mines

Mining Activity

No mining has occurred, but prospecting and limestone quarrying have taken place in the study area. Unpatented mining claims for marble are along parts of Bars Canyon and Marble Wash within the study area and north of it. The following information on nearby mining
districts and a mining area is summarized from Hose and Blake (1976) and Smith (1976).

The Marble Canyon mining district encompasses the Marble Wash area and the region north of it (fig 1). Marble claims were first located in 1891 . No production records are (a) source. Pink-colored marble was tested for crushed stone from 1966 to 1969 . Results of these tests have not been located.
The White Cloud mining district is just west of the Marble Canyon district (fig. 1; Kness, 1989). The Lead King mine, the only one in the district, is near the summit of White Cloud Mountain, 7 to 8 mi northwest of the study area. Recorded district production from 1949 to lead, and 1,553 tb zinc valued at $\$ 4,481$ at the time it was mined. No other information on the lead, and 1,55316 is
district was found

The Mount Moriah mining area, in the Humboldt National Forest, is named for mines and prospects on and around Mount Moriah (fig. 1). This mining area has produced quartzite View tungsten garnet abrasives, gold, silver, copper, lead, and gne Wood, 1983). The Grand scheelite enclosed in $3 \mathrm{ft}$ of silicified limestone shows as much as 7 percent tungsten oxide (WO $\mathrm{O}_{3}$ ).

OII and Gas

Drilling has occurred near the north boundary of the study area. A dry-hole marker was located in Marble Wash (fig. 2) but no records were located. Oil and gas leases have been filed 作

Results of Fleld Investigation

Smith Creek Adits

The two short Smith $C_{r}$ cek adits are just inside the south boundary of the study area (fig. 2). Barite, calcite, and mang .nese oxide are in northeast-striking detachment-fault breccia zone sirforings due to Middle Cambrian carbonate unit. Samples of fanls breccis contain ancemalous as an unnamed arsenic, beryllium, bismuth, mencury, molybdenum, tungsten, and especially barium and manganese (Kness, 1989, fig. 2). Gold and uranium were not detected, and silver was at detection limits $(0.2 \mathrm{ppm})$. No resources could be defined. The unpatented mining claim $0.5 \mathrm{mi}$ west of the adits is shown in U.S. Bureau of Land Management records but no evidence of workings was found

Limestone and Marble

Large inferred limestone and marble resources are present in the study area but must meet industry standards or specifications in order to be marketable. Limestone carbonate rocks of essentially the same composition and are used in the chemical and construction industries. They have the same end uses and are cut, crushed, or ground to produce a wide var.ety of stone products. Other types of rocks may be utilized or substituted for carbonate rocks: granite, sandstone, and slate may be used as dimension or cut stone, and sand and gravel is frequently used as an alternative to crushed limestone or marble.

Impurities such as chert, clay, iron, organic matter, and silica may affect utilization of carbonate rock. Pure calcitic or dolomitic marble is white; any coloration results from content of the upper marble units in the were noted during the field investigation. The quart: percent but may be as high as 40 percent (Nelson, 1969, p. 335). Therefore the marble is too Most chemical uses require high-calcium limestone containing more than 95 percent
calcium carbonate $\left(\mathrm{CaCO}_{3}\right)$; some uses specify more than 97 percent $\mathrm{CaCO}_{3}$ ( Carr and Rooney, 
1983). Limestone and marble samples in and near the study area contain calcium carbonate ranging from 75.73 to 94.83 percent (Kness, 1989, table 2); thus, the best material in the study area is of marginal quality. In general, marble samples contain, higher percentage of be suitable for chemical uses.

Limestone and marble may be cut and used as dimension stone. Principal uses are in building construction and monuments. Most dimension marble is cut into thin slabs $(0.875$ to 1.25 in.) for use as veneer or curtain wall construction. Quarry blocks typically weigh 15 tons and may be rejected for unacceptable color or, more commonly, structural wnsoundness scale folds may make it impossible to saw satisfactory slabs. Some marble units in the study area are contorted, folded, and fractured. Dimension-stone quarries in general produce a large amount of waste because only about 25 percent of the quarried stone is sent to the mill for sawing, and so percent of that may be lost duste percentages and therefore is less likely to be quarry in this area is likely to have higher waste percentages and therefore is less tikely to be

Marble dimension stone marketability is governed largely by stone availability and aesthetic qualities (uniform color, patterns, and texture) determined by architects and architectural fashions. A new prospect or deposit may be successful if it matches or closely matches a currently fashionable stone available in large quantities (see Power, 1972). Marble production continues in traditional areas that have favorable geology and market proximity such as the Pittsford district in Vermont and the Tate district in Georgia. Significant tonnage of marble dimension stone is imported from Italy. Further testing is necessary to determine if marble in and near the study arca is sritable qualities of the stone are larely une present in some marble units. It is not known whether large, uniform, sound blocks are present. Selective mining might be required if suitable marble units are identified. Transportation costs are high because of weight and the need for special handling to prevent finished-stone damage.

Limestone and marble may be crushed and used as aggregate. A private mining consultant's report (L.C. Armstrong, EJ. Longyear and Co., written commun., 1970) estimated that the Marble Wash deposit contains marble is a high-bulk, low-uni-value commos. 1983). The distance from the Marble Wash marble deposits to U. H. Highway 6 and 50 is about $37 \mathrm{mi}$ and Ely, Nev. is the closest market, another 75 mi away. Transportation costs exceed the value of the commodity.

\section{Conclusions}

Large inferred subeconomic limestone and marble resources are present in the study area; however, these rocks were determined to have no special or unique properties. Low calcium carbonate content may preclude utilization for cheies folds and fractures may make it unsuitable marble are unknown, and the prese the carbonate rocks are suitable for use as aggregate, the for dimension stone. Even though the carbonate rocks are suable for use as aggregate, the cins development of the carbonate rocks for all but local uses. Local demand at present is nonexistent. No nearby markets were identified, and similar quality tesources are present elsewhere.

\section{ASSESSMENT OF MINERAL RESOURCE POTENTIAL}

By Michael F. Diggles, Gary Nowlan, H. Richard Blank, Jr., and Susan M. Marcus U.S. Geological Survey

Geology

Rocks not exposed at the surface within the Marble Canyon Wilderness Study Area presumably present ardept, include the Proterozoic and Lower Cambrian Prospect Mountai argillite. Exposed rocks in the study area consist of a lower plate of Middle and Upper Cambria metamorphosed sedimentary rocks in detachment-fault contact with an upper plate of Lower Cambrian through Devonian limestone, dolomite, shale, and quartzite that have mostly undergone only brittle deformation. From Late Proterozoic through Early Triassic, the region of the study area was the site of relatively continuous continental shelf sedimentation (Stewart and Cretaceous and underwent retrograde metamorphism to amphibolite facies during the Cretaceous and underwent retrograde metamorphism to greenschist facies in the Tertiary (J. Lee

Lower-Plate Rocks

The location of the northern Snake Range decollement and the stratigraphy of the upper and lower plates were modified from the early work of Hose and Blake $(1970,1976)$ by Jeffrey Cambrian rocks (figer plate of the decollement within the study area includes Middle and Upper Cambrian rocks (fig. 2). Elsewhere in the northern Snake Range, the décollement cuts through
the Middle Cambrian Pole Canyon Limestone (Huggins and Wright, 1989).

Middle Cambrian rocks consist of the Raiff Limestone of Young (1960) and the Monte combined on figure 2 (map unit Grm). The Middle Cambrian rocks are interrupted by faulsing erosion everywhere in the study area, and their total thickness is not known. inupted by faulting or The Upper Cambrian Notch Peak Limestone and Dunderberg Shale are also combined on figure 2 (map unit Gnd). The Dunderberg consists mostly of light-olive-gray to medium-olivegray silty shale intercalated with thin beds of limestone. It is only about $70 \mathrm{ft}$ thick in the study area. The Notch Peak Limestone, which underlies most of the study area, is medium-gray, massive, locally dolomitic, and contains lenses of chert. The basal part is thin bedded and silty. highest resource potential. Whitchread unit include the marble for which the area has the Notch Peak Limestone south of the study area.

Upper-Plate Rocks

The oldest rocks exposed in the study area are Lower Cambrian shale and quartzite (map unit $6 s q$ ) that include the Pioche Shale. The Pioche consists of 150 to $600 \mathrm{ft}$ of dark-greenishgray to olive-gray silty shale and clay shale intercalated with siltstone and includes some block in the southwest part of the study area. Where the Pioche is metamorphosed within the study area, metamorphic minerals include biotite, muscovite, and garnet. The Middle Cambrian Monte Neva Formation and Raiff Limestone (map unit Grm) comprise the rocks in many small exposures of the upper plate in the northern part of the study area. The Upper Cambrian Notch the study area, where the northem Snake Range decollement lies within it in most places. 
coincides with the time of movement on the Sevier thrust belt east of the study area (Miller and others, 1988a; Miller and Gans, 1989a, 1990).

Tertiary metamorphism is shown by ductile strain that produced penetrative foliation in the Paleozoic rocks of the lower plate of the northem Snake Range decoliement (Milier and thers, 1956). Po70) and argon ages on micas from lo wer-plate recks yieid Tertiary ages (D. recently as the Miocene (J. Lee and others, 1988; J. Lee, 1990).

The northern Snake Range decollement is interpreted by Miller and others (1983) and Gans and others $(1985,1986)$ to have developed as a ductile-brittle transition zone at a depth of 3.8 to $4.4 \mathrm{mi}$. The detachment took place during the doming of the decollement (Miller and others, 1983; McCarthy, 1986) and the extension of this part of the Basin and Range province. The uplift and detachment represent an Oligocene to Miocene event (Miller and others, 1987). The rocks above the decoliement underwent two generations of east-dipping high-angle normal decollement (Gans and Miller, 1983).

Basin-and-Range-type high-angle normal faulting in the Snake Range started in the early to middle Oligocene (Gans and others, 1989) and has occurred conte Rauly since then. It is Normal faults cut volcanic rocks 35 m. y, in age (Gans, 1987). Miller and Gans (1989b) put age constraints on the relative uplift of the range and downdropping of the adjacent basins from about 17 to $15 \mathrm{Ma}$ and 11 to $13 \mathrm{M}$.

Geochemistry

A reconnaissance geochemical survey of the Marble Canyon Wilderness Study Area was conducted in May 1987 . Stream-sediment samples that were collected fro al all major streams and tibutaries represent eroded bedrock that underiles the drainage basin whence the sediment panned-concentrate fraction may contain minerals related to metallization processes.

Methods and Background

Samples of sediment were collected at 47 sites on streams draining the wilderness study area and vicinity (fig. 3). Stream-sediment samples represent a composite of material eroded from the drainage basin of the stream sampled. Panned-concentrate samples derived from stream sediment contain selectively concentrated minerals that may be ore related and may include elements not easily detected in stream-sediment samples.

A strearn-sediment sample and a panned-concentrate sample were collected at each site. The sureaste sodinent sample was air dried and then sieved through an 80-mesh stainless-steel prior to an ysis. For the panned-concentrate sample at each site, enough stream sediment was pror to allosis to remove most of the quartz, feldspar, carbonate-rock material, clay-sized material, and organic matter. Most of the panned-concentrate samples were further concentrated by a series of steps that utilized bromoform (specific gravity 2.8) and magnetic separations to produce nonmagnetic heavy-mineral-concentrate samples that include most nonmagnetic ore minerals and accessory minerals such as sphene, zircon, apatite, and rutile. Prior to anaiysis, the 44 nonmagnetic heavy mineral-concentrate samples were pulverized to minus-100 mesh size.

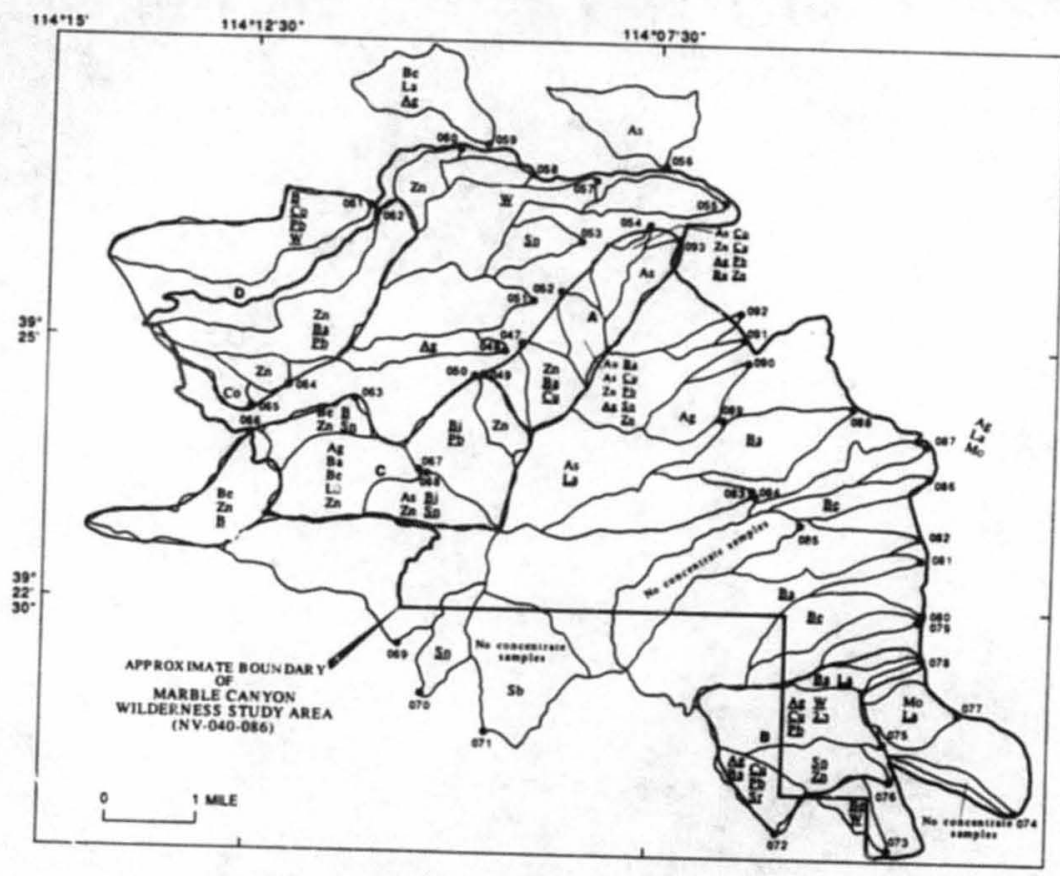

Explanation

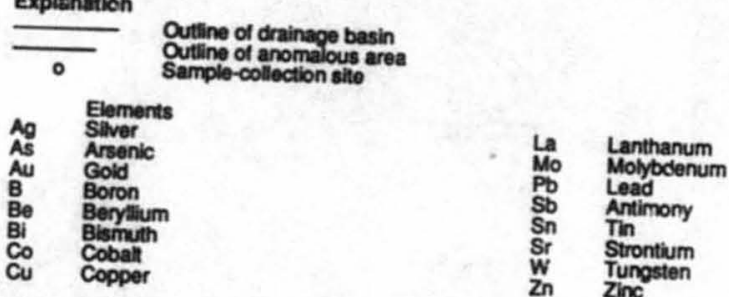

Figure 3.-Geochemical anomaly map of Marble Canyon Wildemess Study Area Nevad a Utah. Concentrationz of As-i, Sb-i, and Zn-i determined spectroscopy, Au-a determined by atomic absorption, and other concentrations plasma heavy heav-minem-concentrate sample; other elements anomalous in minus-80-mesh agnetic 
The stream-sediment and nonmagnetic heavy-mineral-concentrate samples were
nalyzed by emission spectrography for antimony, arsenic, barium, beryllium, bismuth, boron, cadmium, calcium, chromium, cobalt, copper, gold, iron, lanthanum, lead, magnesium, ungsten, vanadium, ytrium, zinc, and zirconium. In addition, the nonmagnetic heavy-mineral. concentrate samples were analyzed for gallium, germanium, palladium, phosphorus, platinum, and sodium by emission spectrography. The stream-sediment samples were also analyzed for gold by graphine-furnace atomic absorption, for uranium by uly wholet huorimetry, and for (ICP). Analytical data, sampling sites, and references to analytical methods are presented by Bullock and others (1989).

Results and Interpretation

Table 1 lists selected element determined in each sample type and for each of them the lower and upper limits of determination, the range of concentrations, the SOth and 90 th percen concentrations, and the threshold (iighest background) concentrations. Threshold number of samples that have anomalous concentrations of each selected element is also

Elements in table 1 that are present in anomelous concentrations in samples from various sampling sites are shown on figure 3 . The elements selected for inclusion in table 1 and on concentrations of beryllium and lanthanum are unusual in the absence of igneous a cous prodominance of carbonate mocks in the sampled ares: these two elements are usually associated with granitic rocks or pegmatites. The average concentration of beryllium in limestone is less than 1 part per million (ppm), and the average concentration of lanthanum in limestone is $4 \mathrm{ppm}$ Rine) in mineral leposits but also commonly forms bedded barite deposits in sediments (copper, lead, that have no significant amounts of base metals. Therefore, it is not unusual that anomalous concentratiors of barium in samples sometimes accompany anomalous concentrations of other elements and sometimes do no.

Many samples from throughout the study area contain anomalous concentrations of only none. Samples from a few draina ge basins of two to eight elements. Several geochemically anomalous areas, delineated A-D on figure 3. have similar geochemical signatures that are centered on anomalous concentrations of lead and inc. The anomalous concentrations of lead and zitc are accompanied by anomalous anthanum, tin strontium, or ingsten; silver and gold ere considered the most important forter lead and zinc. The intensity if the geochervical anomaly of area $\mathrm{A}$ is the greatest, and that of area $D$ is the least.

Anomalous areas A-D include a few adjoining drainage basins that have single-element Berylium and lanthanum are not included as contributors to multiple-element anomalies. When they are omitted, a few basins having them become single-element basins and are not included in the anomalous areas. However, an anomalous concentration of any element
may be significant, and figure 3 only portrays relative significance.
Table 1. Statistics for selected elements in drainage samples collected in and near the Marble Canyon Wilderness Study Area, White [Results based on anlayses of 47 stream-sediment samples and 44 nonmagnetic heavy-mineral-concentrate samples. Determined by inductively coupled plasma spectroscopy for As-i, Sb-i, and Zn-i, by alomic absorpton for Au-a, and by emission spectrography for

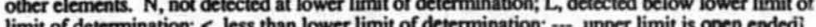

Element Limits of determination. ppm Range, ppm Bercentiles. pom concentration, $\begin{gathered}\text { Number of samples } \\ \text { having anomalous }\end{gathered}$

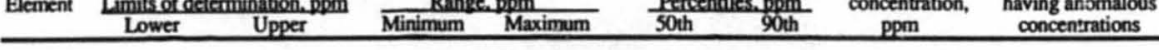
Minus-80-mesh stream-sediment sumples

\begin{tabular}{|c|c|c|c|c|c|c|c|c|}
\hline $\begin{array}{l}A_{B} \\
A_{s-i} \\
A_{w-2} \\
B a \\
B \\
L_{a} \\
M_{0} \\
S b-i \\
Z_{n} \\
Z_{n-1}\end{array}$ & $\begin{array}{c}0.5 \\
5 \\
0.001 \\
20 \\
1 \\
20 \\
5 \\
2 \\
200 \\
2 \\
\end{array}$ & $\begin{array}{r}5,000 \\
20,000 \\
- \\
5,000 \\
1,000 \\
1,000 \\
2,000 \\
20,000 \\
10,000 \\
18,000 \\
\end{array}$ & $\begin{array}{r}\mathrm{N} \\
< \\
< \\
150 \\
\mathrm{~N} \\
\mathrm{~N} \\
\mathrm{~N} \\
\mathrm{c} \\
\mathrm{N} \\
11\end{array}$ & $\begin{array}{c}\mathrm{L} \\
36 \\
0.007 \\
1.500 \\
5 \\
100 \\
\mathrm{~L} \\
2 \\
\mathrm{~L} \\
60\end{array}$ & $\begin{array}{c}\mathrm{N} \\
8 \\
0.001 \\
300 \\
2 \\
20 \\
\mathrm{~N} \\
\mathrm{~K} \\
\mathrm{~N} \\
39 \\
\end{array}$ & $\begin{array}{c}N \\
16 \\
0.001 \\
700 \\
3 \\
50 \\
N \\
< \\
N \\
53 \\
\end{array}$ & $\begin{array}{l}N \\
14 \\
0.001 \\
700 \\
3 \\
50 \\
N \\
< \\
N \\
49 \\
\end{array}$ & $\begin{array}{r}3 \\
6 \\
1 \\
1 \\
4 \\
3 \\
2 \\
1 \\
4 \\
10 \\
\end{array}$ \\
\hline
\end{tabular}
Ningentic heavy minemleancentrate samples

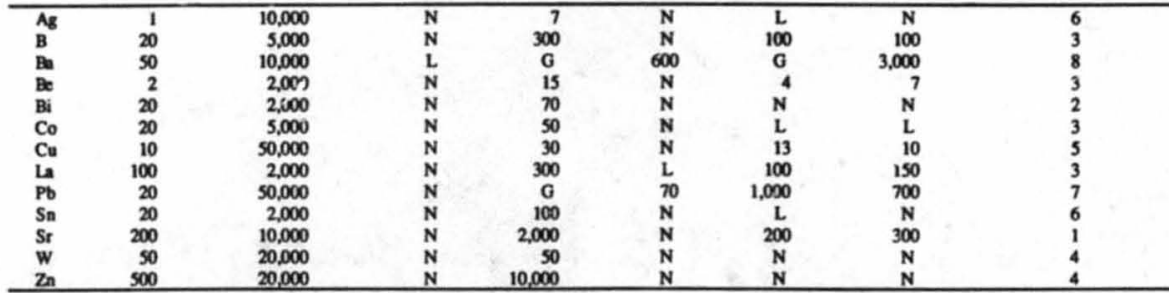


Samples from some drainage basins contain anomalous concentrations of from one to many elements (fig. 3). Except for beryllium and lanthanum, the elements present in anomalous concentrations are compatible with the possible existence of at least two models of mineral deposition. The first model is the polymetallic replacement deposit (Momis, 1986, Mosier and Spencer and Welty, 1986).

A carbonate replacement deposit, the Silver Peak mine, is about $5 \mathrm{mi}$ southwest of the wilderness study area. Recorded production from the mine is $275 \mathrm{oz}$ silver, $0.06 \mathrm{oz}$ gold, and about $38,000 \mathrm{lb}$ of lead (Smith, 1976). Polymetallic replacement deposits characteristically occur in limestone, dolomite, and shale that have been intruded by plutons (Morris, 1986). Igneous bedrock is not present in the sampled area but intrusions are less than $2 \mathrm{mi}$ from the southwest side of the wilderness study area, and volcanic rocks are less than 1 mi from the east side (Hose and Blake, 1976). Igneous rocks that were not detected in the geophysics study may be present beneath the upper-plate ternin that covers extensive areas of the wilderness study beryllium ind lanthanum as well as the elements that are included in the geochemical signature interpred here as possitly representing carbonate replacement deposits related to igneous intrusions. Barton (1987) observed that two-mica granites that intrude carbonate host rocks can give rise to a characteristic lithophile-element suite that includes beryllium, fluorine, tungsten, molybdenum, and zinc.

The cetachment-fault model of mineral deposition (Spencer and Welty, 1986) does not require the presence of igneous rocks. The most intense geochesical anomalies in the sampled

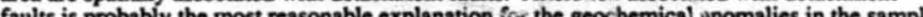
in the sampled

Geophysics

Regional aeromagnetic and gravity maps for the Marble Canyon Wilderness Study Area and vicinity have been examined for indications of mineral resources. Two sources of aeromagnetic data have been utilized: surveys of the Ely, Nev., and Delta, Utah, $1^{*} \times 2^{*}$ quadrangles flown for the National Uranium Resolace Evaluation (NURE) program, and a survey of east-central Nevada flown for the U.S. Geological Survey (U.S. Geological Survey.
1978 ). The NURE traverses were flown east-west at a nominal 400 ft above ground and 3-mi 1978). The NURe US. Gerses were

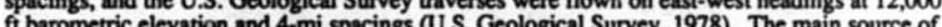
gravity date was the National Solar-Terrestrial and Geophysical Data Center in man source of which supplied principal facts for about 295 stations distributed mainly in low-lying sections of the area of interest. These data were supplemented by thirteen additional stations established during July 1988 specifically to improve coverage in remote portions. It should be noted that the area considered in the aeromagnetic interpretation is necessarily much larger than the area encompassed by the wilderness study area boundaries; only seven stations lie within the wilderness study area.

Aeromagnetic data

The anomalous aeromagnetic field after removal of the International Geomagnetic Reference field (IGRF) was computed from data of the NURE surveys (fig. 4). Because the traverse spacing is wide compared to the flight elevation, the shapes of short-wavelength features Volcanic rocks, which crop out in the northern part of the map area, have aeromagnetic signatures ranging from negligible to very intense and of relatively short wavelength 

Long-wavelength positive anomalies of unknown onigin north and southwest of the widermess wildemess study area occupies a broad, west-northwest-trending anomaly trough between relatively positive areas where the field is more disturbed; the origin of this trough is speculative, but it may reflect a structural depression in the crystalline basement. No aeromagnetic evidence suggests that the wilderness study area is underlain by intrusive rocks or contains concealed structural discontinuities. However, the Jurassic and Cretaceous two-mica granites of the region are notable for their absence of a strong aeromagnetic signature (Grauch and others, 1988).

Gravity data

The complete-Bouguer anomaly field, terrain-corrected to a distance of $42 \mathrm{mi}$ (HayfordBowie zones A-O), is shown in figure 5 . All data reduction and terrain corrections employed Bowie 2os A. (see, for example, Cordell and others, 1982). The anomalous gravity field bears little resemblance to the aeromagnetic field. The anomalies have no direct correlation of anomalies with outcrops of volcanic or intrusive rocks; the oily apparent consistency is that the most positive areas are largely associated with exposed bedrock. The main sources of positive anomalies are expected to be thick sections of Palcozoic miogeoclinal carbonate rocks or possibly carbonate rocks that have 9 core of elevated Proterozoic crystiline basement. A significant maximum, possibly reflecing a basement rise (Hose, 1981), occurs 5 to $6 \mathrm{mi}$ sontheast of Mo morith. Mcur in the Snake Valley to the east or in Spring Valley and adjuncts to the west of the wilderiers study area $A$ majo side of the Snake Range is indicated by the steap ano wilderness study area, several miles east of the nearest outcrops; terrain between this feature and the range front is probably an extensive pediment. No structural discontinuities can be identified from the gravity field within the boundaries of the wilderness study area. Absence of

geophysical evidence of buried plut ns reduces the likelihood that there may be pluton-related resources at depth. Such a platon could be present, but only if it lacked a notable aeromagnetic signature; the data are pernissive for the presence of a buried two-mica granite such as those described by Grauch and others (1988).

The gravity field southwest of figure 5 is not well constrained, but anomaly values that appear to fall off steadily to the southwest toward Sacramento Pass suggest an increase in direction.

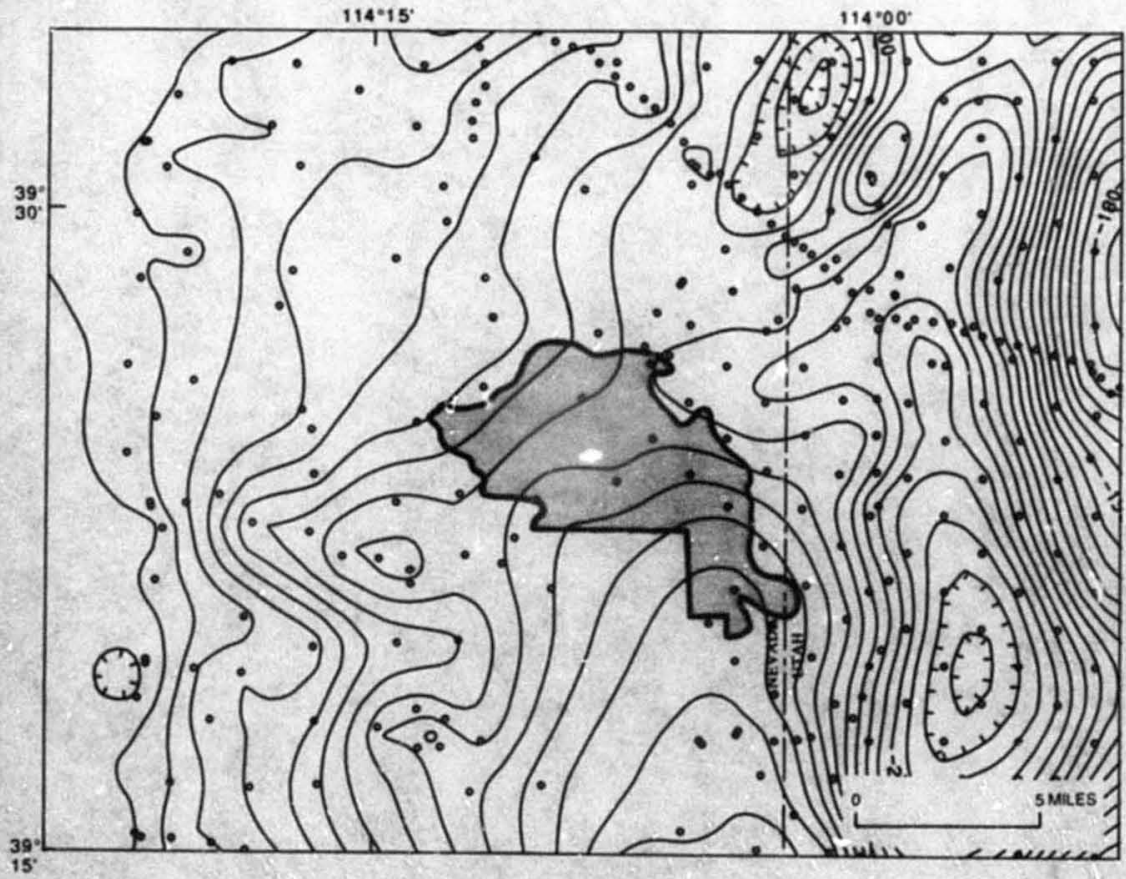


Mineral Resource Potential

Limestone and Marble

The lower parts of Bars Canyon and Marble Wash have high mineral resource potential, certainty level D, for medium-purity limestone and marble for use as aggregate. The rest of the wilderness study area may have pockets of medium-purity limestone and marbie, although none that have the purity of that observed in the canyons were. The rest of the wilderness study arca, as aggregate.

Gold and Silver

Parts of the Marble Canyon Wilderness Study Area underiain by rocks of the upper plate and the zone of the nurthem Snake Range decollement have low mineral resource potential for gold and silver associated with detachment faults. Bouley (1986) has described detachmentfault-type deposits. As so few such deposits are being mined, a grade-tonnage model has yet to be developed (D.A. Singer, oral commun., 1989). Gans and others (1988) suggests that the northerm Snake Range decoliement may be a rotated normal fault. If this is the case, the appropriane silver is low, certainty level $C$ in the southeast side of lower Bars Canyon, where the zeochemical data more strongly support this assessment. Other areas near the dtecollement, including both the upper and lower plates, have low mineral resource potential, certainty level B, for gold and silver.

\section{Copper, Lead, and Zinc}

Geochemical evidence saggests that parts of the study area underlain by the upper-plate rocks and the zone of the northern Snake Range decollement or projections of that structrre and others, 1984), have low resource potential, certainty level B, for copper, lead and anc.

Tungsten and Molybdenum

The geophysical study does not suggest that plutons are concealed beneath the sthiy area, but the two-mica granites of the region are notable for their lack of geophysical expression (Grauch and others, 1988). Anomalous cuncentrations of tungsten and (or) molybdenum in stream-sediment and faul-breccia samples collected from scattered parts of the study area could be explained if a buried pluton were present. The detachment fault could also have provided a locus for concentration of the metals. Parts of the study area underlain by the upper-plate rocks and the zone of the northern Snake Range décollernenter

Beryllium and Fluorite

Although there are beryllium and fluorite deposits in the Pioche Shale about $30 \mathrm{mi}$ to the south in the Wheeler Peak region in the southern Snake Range (Whitebread and Lee, 1961), those deposits are confined to an (infommal) limestone unit locally known as the "Wheeler limestone" in the lower part of the Pioche. A possible source of the beryllium is a quartz monzonite stock that intrudes the Wheeler Peak area (Whitebread and Lee, 1961). The Pioche Shale (part of map unit Gsq) crops out in the southwestern part of the study area, but the sothe intrusion of the stock is confined to the Wheeler Peak area. The geophysical study did not show evidence that plutons are buried beneath the study area; however, the Snake Range is known for the presence of two-mica plutons that have no geophysical signature (Grauch and others, 1988). Anomalous concentrations of beryllium in geochemical samples collected from fault could also have provided a locus for concentration of the beryllium. Pants of detachment fault could also have provided a locus for concentration of the beryllium. Parts of the study area low mineral resource potential, certainty B, for beryllium and fluorite.

Barite

Barite is present in the walls of two adits that are just inside the southeast boundary of the study area (Kness, 1989), and anomalous concentrations of barium (greater than $10,000 \mathrm{ppm}$, Bullock and others, 1989) were measured in the panned concentrate from the basin containing the adits. Therefore, a zone around the adits has moderate mineral resource potential, certainty for barite also have low miners resource potential, certainty level $B$, for silver, copper, lead, ainc, and tungsten.

Oil and Gas

Sandberg $(1982,1983)$ evaluated the petroleum potential of wildemess lands in Nevad using the following four major parameters that govern oil and gas accumulation: presence of source rocks, hydrocarbon maturation, reservoir rocks, and traps. He rated the Marble Canyon Wilderness Study Area as having medium potential because of optimum maturity of source rocks in the Devonian and Mississippian Plot Shale and the Mississippian Chainman Shale. However, metamorphosed lower-plate rocks, thin sequences of faulted upper-plate rocks, and Therefore, the oil and gas resource potential is moderate in the entire study area but on the basis of the degree of metamorphism of the possible lower-plate source rocks and the faulting and tilting of possible upper-plate tonp rocks, this assessment could be too high. The certainty level of assessment, therefore, is B.

Geothermal Energy

Bliss (1983) lists geothermal springs and wells for the Ely $1^{*}$ by $2^{*}$ quadrangle. He shows two thermal springs in Spring Valley to west of the study area. We observed therma springs just east of the study area, 1 mi across the Nevada-Utah State line on the road to Gandy. ange-lont faulting may be providing a conduit for thermal water, and that system could extend energy potential, certainty level B, fo low-

\section{REVERENCES CITED}

F -ebv, W.C., Menzie, W.D., Mosier, D.L., and Singer, D.A., 1986, Grade and tonnage model of carbonate-hosted Av-Ag, in Cox, D.P., and Singer, D.A., eds., Mineral deposit models: U.S. Geological Survey Bulletin 1693, p. 175-177.

Barton, M.D., 1987, Lithophile-element mineralization associated with Late Cretaceous twomica granites in the Great Basin: Geology, v. 15, p. 337-340.

Beikman, H.M. Finkle, M.E., Frieders, Twila, Marcus, S.M., and Edward, J.R., 1983, Minera surveys by the Geological Survey and the Bureau of Mines of Bureau of Land 
Berger, B.R., 1986, Descriptive model of carbonate-hosted Au-Ag, in Cox, D.P., and Singer,
D.A., eds., Mineral deposit models: U.S. Geological Survey Bulletin 1693, p. 175.

Bliss, J.D., 1983, Nevada-Basic data for thermal sprints and wells as recorded in GEOTHERM. part A: U.S. Geological Survey Open-Fi:e Report 83-433-A, 101 p.

Bouley, B.A., 1986, Descriptive model of gold on flat faults, in Cox, D.P., and Singer, D.A., eds., Mineral deposit models: U.S. Geological Survey Bulletin 1693, p. 251

Bullock, J.H., Jr., McHugh, J.B., Briggs, P.H., and Nowlan, G.A., 1989, Analytical results and sample locality map for stream-sediment and nonmagnetic heavy-mineral-concentrate County, Nevada: U.S. Geological Survey Open-File Report 89-0024, 11 p.

Carison, R.R., Martin, R.A., and Wood, R.H., II, 1984, Mineral resource potential map of the Mount Moriah Roadless Area, White Pine County, Nevada: U.S. Geological Survey Miscellaneous Field Studies Map MF-1244-B, scale 1:62,500.

Carr, D.D., and Rooney, L.F., 1983, Limestone and dolomite, in Lefond, S.J., ed., Industrial minerals and rocks, 5th ed., V. 2: New York, Society of Mining, Metallurgical, and Petroleum Engineers, Inc., p. 833-868.

Coney, P.J., 1974, Structural analysis of the Snake Range "décollement," east-central Nevada: Geological Society of America Bulletin, v. 85, no. 6, p. 973-978.

Cordell, Lindrith, Keller, G.R., and Hildenbrand, T.G., 1982, Bouguer gravity map of the Rio Grande rift, Colorado, New Mexico, and Texas: U.S. Geological Survey Geophysical Investigations Map GP-949, scale 1:1,000,000.

Christiansen, P., Cladouhos, T., DeBari, S., El-Shazly, A, Gans, E., Gans, P., Gehrke, I., Grissom, G., Huggins, C., Jones, C., Lee, J., Lomas, M., Miller, E., Minobe, W.., Pinto, M., Riley, T., Stahl, D., and Thomas, A., 1987, Geologic map of the Horse Canyon/Smit Creek area of the northern Snake Range, White Pine County, Nevada: Stanford, C $1: 12,000$ [available at the main library].

Cox, D.P., and Singer, D.A., eds., 1986, Mineral deposit models: U.S. Geological Survey Bulletin $1693,379 \mathrm{p}$.

Crittenden, M.D., Jr., Coney, P.J., and Davis, G.H., eds., 1980, Cordilleran metamorphic core complexes: Geological Society of America Memoir 153, 490 p.

Darton, N.H. 1908, Building stones-Marble of White Pine County, Nev., near Gandy, Utah: U.S. Geological Survey Bulletin 340-G. pt. 1, p. 377-380.

Gans, P.B., 1987, Cenozoic extension and magmatism in the eastern Great Basin: Stanferd, Calif., Stanford University Ph.D. dissertation, 174 p.

Gans, P.B., Clark, D.H., Miller, E.L., Wright, M.E., and Sutter, J.F., 1986, Structural development of the Kerm Mountains and northem Snake Range [abs.]: Geological Society of America Abstracts with Programs, v. 18, no. 2, p. 108
Gans, P.B., Mahood, G.A., and Schermer, Elizabeth, 1989, Synextensional magmatism ta the Basin and Range Province; a case study from the eastem Great Basin: Geological Society of America Special Paper 233, 53 p.

Gans, P.B., and Miller, E.L., 1983, Style of mid-Tertiary extension in east-central Nevada, in Gurgel, K.D., ed., Geologic excursions in the overthrust belt and metamorphic core complexes of the intermountain region, Guidebook-Part 1, GSA Rocky Mountain and 59, p. 107-160.

Gans, P.B., Miller, E.L., McCarthy, Jill, and Ouldcott, M.L., 1985, Tertiary extensional faulting and evolving ductile-brittle transition zones in the northern Snake Range and vicinity: new insights from seismic data: Geology, v. 13, p. 189-193.

Gans, P.B., Lee, Jeffrey, Miller, E.L., Kunk, Mick, and Sutter, J.F., 1988, Uplift history of midcrustal rocks in the eastem Great Basin [abs.]: Geological Society of America Abstracts with Programs, v. 20, no. 7, p. A17.

Gering, R.L., 1987, A study of the metamorphic petrology of the northern Snake Range, eastcentral Nevada: Dallas, Tex., Southern Methodist University M.S. thesis, 75 p.

Goudarzi, G.H., 1984, Guide to preparation of mineral survey reports on public lands: U.S. Geological Survey Open-File Report 84-787, 51 p.

Grauch, V.J.S., Blakely, R.J., Blank, H.R., Oliver, H.W., Plouff, Donald, and Ponce, D.A., 1988, Geophysical delineation of granitic plutons in Nevada: U.S. Geological Survey OpenFile Report 88-11, scale $1: 1,000,000,2$ plates.

Great Basin GEM Joint Venture, 1983, Granite Spring G-E-M resources area (GRA No. NV-09) technical report (WSA NV 040-086): U.S. Bureau of Land Management Contract YA. 554-RFP2-1054, $49 \mathrm{p}$.

Hazzard, J.C., Misch, Peter, Wiese, J.H., and Bishop, w.C., 1953, Large-scale thrusting in northem Snake Range, White Pine County, Nevada

Hose, R.K. 1981, Geological map of the Mount Moriah Further Pianning (RARE II) Area eastern Nevada: U.S. Geological Survey Miscellaneous Field Studies Map MF-1244-A, scale 1:62,500.

Hose, R.K., and Blake, M.C., Jr., 1969, Structural development of the eastern Great Basin during the Mesozoic [abs.]: Geological Society of America Abstracts with Programs for 1969. part 5, p. 34

1970, Geologic map of White Pine County, Nevada: U.S. Geological Survey open-file map, scale 1:150,000.

1976, Part I, Geology, in Hose, R.K., Blake, M.C., Jr., and Smith, R.M., Geology and Bulletin 85, p. 1-35.

Hose, R.K., and Daneš, Z.F., 1968, Late Mesozoic structural evoiution of the eastern Great Basin [abs.]: Geological Society of America Special Paper 115, p. 102. 
Miller, E.L., and Gans, P.B., 1989a, Cretaceous crustal structure and metamorphism in the hinterland of the Sevier thrust belt, western U.S. Cordillera: Geology, v. 17, p. 59-62

_ 1989b, Uplift history of the Snake Range metamorphic core complex, Basin and Range province, USA, from apatite fission

1990, Comment and reply on "Cretaceous crustal structure and metamorphism in the hinterland of the Sevier thrust belt, western Ü.S. Cordillera": Geology, v. 18, p, 577-578

Miller, E.L., Gans, P.B., and Garing John, 1983, Snake Range décollement: an exhumed midTertiary ductile-brittle transition: Tectonics, v. 2, p. 239-253.

Miller, E.L., Gans, P.B., and Lee, Jeffrey, 1987, The Snake Range décollement, eastern Nevada: Geological Society of America Centennial Field Guide, Cordilleran Section, p. 77-82.

Miller, E.L., Gans, P.B., and Wright, J.E., 1988a, Cretaceous crustal structure and metamorphism, hinterland of Sevier thrust belt, Nevada and Utah [abs.]: Geological Society of America Abstracts with Programs, v. 20, no. 7, p. A18.

Miller, E.L., Gans, P.B., Wright, J.E., and Sutter, J.F., 1988b, Metamorphic history of the eastcentral Basin and Range province: tectonic setting and relationship to magmatism in Emst, W.G. ed, Metamorphism and crustal evolution of the western United States: Englewood Cliffs, N.J., Prentice-Hall, Rubey Volume VII, p. 649-682.

Misch, Peter, 1960, Regional structural reconnaissance in central-northeast Nevada and some adjacent areas-observations and interpretations in Boettcher, J.W., and Sloan, W.W., ede. Geology of east-central Nevace. Salt Lake City, Utah, 1960 Guidebook, p. 17-42.

Misch, Peter, and Hazzard, J.C., 1962, Stratigraphy and metamorphism of late Precambrian rocks in central northeastern Nevada and adjacent Utah: American Association of Petroleum Geologists Bulletin, v. 46, no. 3, p. 289-343.

Morris, H.T., 1986, Descriptive model of polymetallic replacement deposits, in Cox, D.P., and Singer, D.A., eds, Mineral deposit models: U.S. Geological Survey Bulletin 1693, p. 99

Morton, J.L., Silberman, M.L., Bonham, H.F., Jr., Garside, L.J., and Noble, D.C., 1977, K-Ar ages of volcanic rocks, plutonic rocks, and ore deposits in Nevada and eastern California20 , p. $19-29$.

Mosier, DL., Morris, H.T., and Singer, D.A., 1986, Grade and tonnage model of polymetallic replacement deposits, in Cox, D.P., and Singer, D.A., eds., Mineral deposit models: U.S. Geological Survey Bulletin 1693, p. 101-104.

Nelson, R.B., 1966, Structural development of northernmost Snake Range, Kern Mountains, and Deep Creek Range, Nevada and Utah: American Association of Petroleum Geologists Bulletin, v. 50, p. 921-951.

1969, Relation of history of structures in a sedimentary succession with deeper metamorphic structures, eastern Great Basin: American Association of Petroleum Geologists Bulletin, structures, eastern
v. 53, p. 307-339.
Nolan, T.B., Menriam, C.W., and Williams, J.S., 1956, The stratigraphic section in the vicinity of Eureka, Nevada: U.S. Geological Survey Professional Paper 276, 77 p.

Palmer, A.R., 1960, Some aspects of the early Upper Cambrian stratigraphy of White Pine County, Nevada, and vicinity, in Boettcher, J.W., and Sloan, W.W., eds., Geology of Field Conference, Salt Lake City, Utah, 1960 Guidebook, p. 53-58.

Power, W.R., 1972, An evaluation of building dimension stone deposits: Mining Engineering. vol. 24 , no. 6 , p. $42-44$.

_ 1978, Economic geology of the Georgia marble district, in Twelfth forum on the geology of industrial minerals: Georgia Geologic Survey Information Circular 49, p. 59-68.

Robison, R.A., 1960, Lower and Middle Cambrian stratigraphy of the eastem Great Basin, in

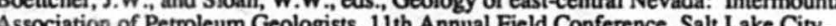
Utah, 1960 Guidebook, p. 43-52

Rose, A.W., Hawkes, H.E., and Webb, J' , 1979, Geochemistry in mineral exploration, 2 d edit. London, Academic Press, $657 \mathrm{p}$.

Rowles, L.D., 1982, Deformation history of the Hampton Creek area, northern Snake Range, Nevada: Stanford, Calif., Stanford University M.S. thesis, 80 p.

Sandberg, C.A., 1982, Petroleum potential of wilderness lands, Nevada: U.S. Geological Survey Miscellaneous Geologic Investigations Map -1542, scale 1:1,000,000

_ 1983, Petroleum potential of wilderness lands in Nevada, in Miller, B.M., ed., Petroleum potential of wilderness lands in the Western United States: U.S. Geological Survey Cotential of wilderness lands in $902-\mathrm{H}, \mathrm{p}$. H1-H11.
Circular

Schenck, G.K., and Torries, T.F.K., 1983, Crushed stone, in Lefond, S.J., ed., Industrial Minerals and rocks; Sth ed., vol., 1: New York, Society of Mining, Metallurgical, and Petroleum Engineers, Inc., p. 60-80

Sherlock, M.G., and Tingley, J.V., 1985, Nevada mineral-resource data: information available through the U.S. Geological Survey Mineral Resource Data System: U.S. Geological Survey Circular $966,35 \mathrm{p}$.

Smith, R.M., 1976, Part II, Mineral resources, in Hose, R.K., Blake, M.C. Jr., and Smith, R.M. Geology and mineral resources of White Pine County, Nevada: Nevada Bureau of Mines Geology and mineral resources of Whith
and Geology Bulletin 85, p. 36-105.

Spencer, J.E., and Welty, J.W., 1986, Possible controls of base- and precious-metal mineralization associated with Tertiary detachment faults in the lower Colorado trough, Arizona and California: Geology, v. 14, p. 195-198.

Steele, Grant, 1960, Pennsylvanian-Permian stratigraphy of east-central Nevada and adjacent Utah, in Boettcher, J.W., and Sloan, W.W., eds., Geology of east-central Nevada: Intermountain Association of Petroleum Geologists, 11 th Annual Field Conference, Salt 
Stewart, J.H., 1970, Upper Precambrian and Lower Cambrian strata in the southem Great Basin California and Nevada: U.S. Geological Survey Proícesional Paper 620, $206 \mathrm{p}$.

Stewart, J.H., Stevens, C.H., and Fritsche, A.E., eds., 1977, Paleozoic paleogeography of the Western United States: Society of Economic Paleontologists and Mineralogists, Pacific
Section, Pacific Coast Paieogrography Symposium 1, 502 p.

U.S. Bureau of Mines and U.S. Geological Survey, 1980, Principles of a resourcc/reserve classification for minerals: U.S. Geological Survey Circular 831, 5 p.

U.S. Geological Survey, 1978, Aeromagnetic map of east-central Nevada: U.S. Geological Survey Open-File Report 78-281, scale 1:250,000.

Weimer-McMillion, Becky, Tingley, S.L., and Shilling, John, 1983, Bibliography of Nevada geology and mineral resources through 1980, an alphabetical listing by author: Nevada Bureas of Mines and Geology Special Publication 7, 184 p.

Wernicke, Brian, 1981, Low-angle normal faults in the Basin and Range Province: nappe tectonics in an extended orogen: Nature, v. 291, p. 645-648.

Whitebread, D.H., 1966, The Snake Range decollement and related structures [abs.]: Geological Society of America Program, 62nd Annual Meeting, Reno, Nev., p. 77.

1969, Geologic map of the Wheeler Peak and Garrison quadrangles, Nevada and Utah: U.S. Geological Survey Miscellaneous Geologic Investigations Map 1-578, scale 1:48,000.

Whitebread, D.H., and Lee, D.E., 1961, Geology of the Mount Wheeler mine area, White Pine County, Nevada, in Geological Survey research 1961: U.S. Geological Survey

Wong. George, 1983, Preliminary map of the resource areas in the Basin and Range Province of Nevada: U.S. Geological Survey Open-File Report 83-721, 37 p.

Wood, R.H., 1983, Mineral inventory of the Mt. Moriah Roadless Area, White Pine County: U.S. Bureau of Mines Open-File Report MLA 50-83, 27 p.

Young, J.C., 1960, Structure and stratigraphy in north central Schell Creek Range in Boettcher, J.W., and Sloan, W.W., eds., Geology of east-central Nevada: Intermountain Associatio of Petroleum Geologists, 11 th Annual Field Conference, Salt Lake City, Utah, 196

\section{APPENDIXES}


DEFINITION OF LEVELS OF MINERAL RESOURCE POTENTIAL

AND CERTAINTY OF ASSESSMENT

LEVELS OF RESOURCE POTENTIAL

H MIGH mineral resource potential is assigned to areas where geologic, geochemical, and geophysical chat. acteristics indicate a geologic environment favorable for resource occurrence, where interpretations of data indicating presence of resources, and where evidence indicales that mint Assignment of high resource potential to an area requires some positive knowledge that mineral-forming processes

Mave been active in at least part of the area.
MODERAT mineral resource potential is assigned to areas where geologic, geochemical, and geophysical
characteristics indicate a geologic emvironment favorable for resource occurrence, where interpretations of data indicate reasonable likelihood for resource accumulation, and (or) where an application of mineral-deposit models indicates favorable ground for the specified typets) of deposits.

Low minera! resource potential is assigned to areas where geologic, geochemical, and geophysical characteristica define a geologic environment in which the existence of resources is permissive. This broad category embraces as areas with little or no indication of having

No mineral resource potential is a category resenved for a speciicic type of resource in a well-defined area.

UNIONOWN mineral resource potential is assigned to areas where information is inadequate to assign a low, maderate, or high level of resource potential.

\section{LEVELS OF CERTAINTY}

A Available information is not adequate for detarmination of the level of mineral resource potential.

Available information only sugegests the level of mineral resource potential.

Available information gives a good indication of the level of minural resouce potential.

Available information clearly defines the level of mineral resource potential.

\begin{tabular}{|c|c|c|c|}
\hline \multirow{3}{*}{$U / A$} & B & c & D \\
\hline & $\begin{array}{c}\text { H/B } \\
\text { HICA POTENTINL }\end{array}$ & $\begin{array}{c}\text { H/C } \\
\text { HICH POTENTINL }\end{array}$ & $\begin{array}{c}\text { H/D } \\
\text { HICH POTENTIN }\end{array}$ \\
\hline & $\begin{array}{c}\text { MVB } \\
\text { MODERATE POTENTUL }\end{array}$ & $\begin{array}{c}\text { MC } \\
\text { MODERATE POTENTUL }\end{array}$ & $\begin{array}{c}\text { MD } \\
\text { MODERATE POTENTUL }\end{array}$ \\
\hline \multirow{2}{*}{ UNKNOWN POTENTLLL } & $\begin{array}{c}\text { L/B } \\
\text { LOWPOtentul }\end{array}$ & $\begin{array}{c}\text { U/C } \\
\text { LOW POTENTUL }\end{array}$ & $\begin{array}{c}\text { LDD } \\
\text { LOWPOTENTUL }\end{array}$ \\
\hline & & & $\begin{array}{c}\text { N/D } \\
\text { NOPOTENTILL }\end{array}$ \\
\hline
\end{tabular}

LEVEL OF CERTAINTY $\longrightarrow$

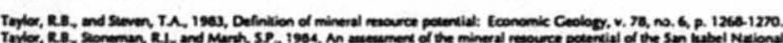

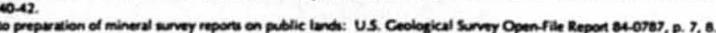

RESOURCE/RESERVE CLASSIFICATION

\begin{tabular}{|c|c|c|c|c|c|}
\hline & \multicolumn{3}{|c|}{ IDENTIFIED RESOURCES } & \multirow{2}{*}{\multicolumn{2}{|c|}{$\begin{array}{c}\text { UNDISCOVERED RESOURCES } \\
\text { Probability Range }\end{array}$}} \\
\hline & \multicolumn{2}{|c|}{ Demonstrated } & \multirow{2}{*}{ Inferred } & & \\
\hline & Measured & Indicated & & Hypothetical & Speculative \\
\hline ECONOMIC & \multicolumn{2}{|c|}{$\begin{array}{c}1 \\
\text { Reserves }\end{array}$} & $\begin{array}{l}\text { Inferred } \\
\text { Reserves }\end{array}$ & \\
\hline $\begin{array}{l}\text { MARGINALLY } \\
\text { ECONOMIC }\end{array}$ & \multicolumn{2}{|c|}{$\begin{array}{l}\text { Marginal } \\
\text { Reserves }\end{array}$} & $\begin{array}{l}\text { Inferred } \\
\text { Marginal } \\
\text { Reserves }\end{array}$ & \multicolumn{2}{|c|}{$-1-$} \\
\hline $\begin{array}{c}\text { SUB- } \\
\text { ECONOMIC }\end{array}$ & \multicolumn{2}{|c|}{$\begin{array}{l}\text { Demonstrated } \\
\text { Subeconomic } \\
\text { Resources }\end{array}$} & $\begin{array}{l}\text { Inferred } \\
\text { Subeconomic } \\
\text { Resources }\end{array}$ & \multicolumn{2}{|c|}{$-i-$} \\
\hline
\end{tabular}

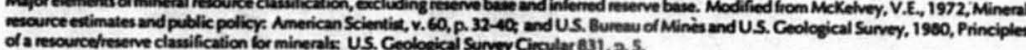

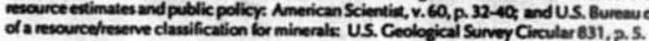


Terms and boundary ages used by the U.S. Geological Survey in this repont

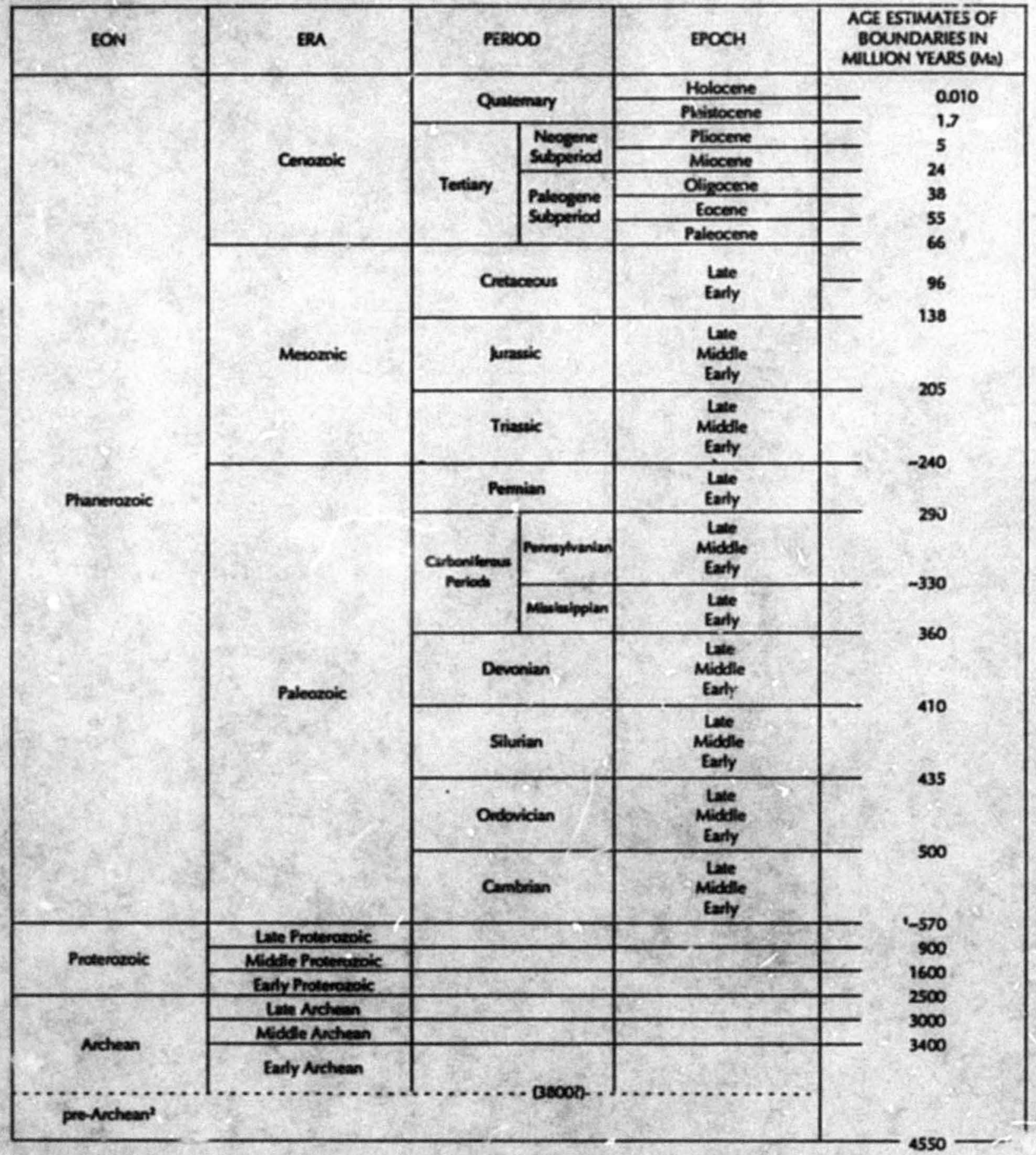

TRocla older than $570 \mathrm{Ma}$ also caicd Precambrian, a time term without specific rank

Fiformal time term without specific rank. 